NBER WORKING PAPER SERIES

\title{
IS CALIFORNIA MORE ENERGY EFFICIENT THAN THE REST OF THE NATION? EVIDENCE FROM COMMERCIAL REAL ESTATE
}

\author{
Matthew E. Kahn \\ Nils Kok \\ Peng Liu \\ Working Paper 21912 \\ http://www.nber.org/papers/w21912
NATIONAL BUREAU OF ECONOMIC RESEARCH
1050 Massachusetts Avenue
Cambridge, MA 02138
January 2016

Kahn thanks the UCLA Ziman Center for Real Estate for generous funding. Kok is supported by a VIDI grant from the Dutch Science Foundation (NWO). Liu thanks United Technology for a research grant. We are grateful to Arik Levinson for useful comments. Any errors are the responsibility of the authors. The views expressed herein are those of the authors and do not necessarily reflect the views of the National Bureau of Economic Research.

NBER working papers are circulated for discussion and comment purposes. They have not been peerreviewed or been subject to the review by the NBER Board of Directors that accompanies official NBER publications.

(C) 2016 by Matthew E. Kahn, Nils Kok, and Peng Liu. All rights reserved. Short sections of text, not to exceed two paragraphs, may be quoted without explicit permission provided that full credit, including (C) notice, is given to the source. 
Is California More Energy Efficient than the Rest of the Nation? Evidence from Commercial

Real Estate

Matthew E. Kahn, Nils Kok, and Peng Liu

NBER Working Paper No. 21912

January 2016

JEL No. Q41,Q48

\section{ABSTRACT}

California's per-capita electricity consumption is 50 percent lower than national per-capita consumption. Mild climate, deindustrialization, and its demographics explain part of this differential. California energy efficiency policy is often claimed to be another key factor. A challenge in judging this claim is the heterogeneity of the real estate capital stock. Residential homes differ along a large number of physical attributes. We access a proprietary dataset from a large hotel chain that allows us to evaluate the environmental performance of comparable commercial real estate across the United States. Controlling for climate conditions and geographic location, we document that California's commercial real estate stock is the most energy efficient at a point in time but this differential is quantitatively small. However, over the years 2007 to 2013, California's hotels achieved much greater energy efficiency progress than hotels in other states.

Matthew E. Kahn

Department of Economics

University of Southern California

KAP

Los Angeles, CA 90089

and NBER

kahnme@usc.edu

Nils Kok

Department of Finance

Maastricht University, Room B1.08

P.O. Box 616

6200 MD Maastricht

The Netherlands

N.Kok@maastrichtuniversity.nl
Peng Liu

Cornell University

465 Statler Hall

Ithaca, NY 14853

United States

pl333@cornell.edu 


\section{Introduction}

In 2010, California's per-capita electricity consumption was 50 percent lower than U.S per-capita electricity consumption. ${ }^{1}$ This large differential may be due to several different factors. California's unique climate requires less winter heating and summer cooling to achieve a given level of comfort. California's high land prices, pro-labor union stance and stringent environmental regulation have all played a role in reducing the count of manufacturing jobs located in the state (Becker and Henderson, 2000, Holmes, 1998).

California is also well known for its leadership with respect to building codes and energy efficiency for new durables (Rosenfeld 1999). ${ }^{2}$ Recent empirical work by Levinson (2014) challenges the conventional wisdom that California's conservation policies are the primary explanation for the state's relative environmental progress. He studies several residential and industrial data sets and concludes that other concurrent demographic and geographic trends are the main reasons explaining differential trends in per-capita energy consumption (Levinson 2014a). In a second empirical study, he rejects the hypothesis that homes constructed since California instituted its building energy codes use less electricity today than homes built before the codes came into effect (Levinson 2014b).

Levinson's research highlights the importance of conducting a standardized comparison. Does a given piece of real estate (such as a home or a commercial building) consume less electricity if this capital is located in California? The ideal

\footnotetext{
${ }^{1}$ See: http://energyalmanac.ca.gov/electricity/us_per_capita_electricity-2010.html. ${ }^{2}$ See: http://www.energy.ca.gov/commissioners/rosenfeld_docs/rosenfeld_effect/presentations/NRDC.pdf.
} 
experiment would be to take buildings of the same vintage, size and purpose and randomly assign them to different sides of the California state border. At such borders, the real estate would be exposed to the same climate conditions and local market circumstances but would face different state regulatory regimes and different electricity prices.

To approximate this experiment, we partner with a major global hotel chain and access monthly electricity consumption of hundreds of its hotels located across the United States and around the world. These hotels feature a common management structure and have several common features that increase our confidence that we are making valid standardized comparisons of energy consumption across space and time.

Commercial real estate is an important contributor to greenhouse gas emissions as the sector is a major electricity consumer, but the United States government has not conducted a representative survey of such buildings since the 2003 CBECS. ${ }^{3}$ This was a small sample survey that included roughly 5,000 observations across different sectors. Our hotel data set allows us to fill in data gaps to evaluate the energy performance of the real estate sector, as it covers all of the major states and even some foreign nations. We rank different states with respect to their standardized energy efficiency - this offers a different test of the "California exceptionalism” hypothesis. We document that California stands out as the most energy efficient state, in accord with its "green" reputation, but its energy efficiency differential relative to the next most efficient state (Ohio) is economically small.

\footnotetext{
${ }^{3}$ The Department of Energy is currently preparing to release the new 2012 wave of CBECS data (see http://www.eia.gov/consumption/commercial/data/2012/index.cfm?view=microdata).
} 
In a second set of results, we include hotel-fixed effects and exploit the withinhotel panel variation to test for trends in energy efficiency using energy consumption per occupied room as the key standardized metric of energy performance. Relative to hotels in other states, the results show that California's hotels are making the greatest progress over time with respect to reducing energy consumption per occupied room.

The results in this paper add to the literature on energy efficiency in the real estate sector. Building codes have been credited for significant energy reductions (see Aroonruengsawat and Auffhammer, 2011 and Jacobsen and Kotchen, 2013. For a dissenting view see Levinson, 2014b). These results focus on the residential building stock, where consumption is determined both by physical buildings characteristics, as well as heterogeneous occupants. Understanding the implications of energy policy on the performance of the commercial real estate sector is important, given the large environmental externality imposed by the sector, and the fact that there is a negative correlation between commercial building vintage and building energy consumption (Kahn et al., 2014).

The rest of this paper is organized as follows: first, to explore the role that electricity prices and regulation play in determining a hotel's monthly electricity consumption, we discuss the economic tradeoffs that individual hotels face at any point in time. We then introduce our data set and econometric approach. Section III reports our results and Section IV concludes.

\section{Hotel Electricity Demand}


At any point in time, a hotel's electricity consumption depends on how the building was constructed, its size, occupancy, and the activities of those who work and stay at the hotel. A hotel uses electricity for a variety of different purposes ranging from lighting, to cooling, to powering the elevators. As formally modeled for the residential sector by Reiss and White (2005), real estate owners demand electricity as an input in a Beckerian production function where the final output is a set of basic services such as comfort, lighting, safety, and entertainment (Michael and Becker, 1973).

In producing comfort, hotel occupants will turn on the air conditioner on hot days. They will take elevators to their room rather than walking up and down the stairs. The cleaning staff will use vacuums to clean the rooms. The guests will use the lights and will plug in durable devices such as televisions and computers to amuse themselves in their room. In the day-to-day operations, the hotel will use electricity in common spaces such as the swimming pool, gym, atrium, restaurant and the common areas. ${ }^{4}$ All of these choices increase hotel electricity demand. These choices in turn depend on past investments in durables, such as the types of windows installed, the roof type and the air conditioning system's efficiency.

As a for-profit, a hotel has strong incentives to invest in durables that are more energy efficient if their purchase price plus the expected present discounted value (PDV) of the operating expenses is less than the total purchase cost plus the PDV of operating the conventional durables. In the hotel business there are three parties

\footnotetext{
${ }^{4}$ Kahn et al. (2014) use data from a single electric utility for many different types of commercial buildings. Using the CoStar data, they know which buildings are rated " $\mathrm{A}$ ", "B", "C" based on quality. Controlling for square footage, vintage and occupancy and other attributes, higher quality real estate consumes more electricity. In the case of hotels, this is also likely to be the case.
} 
involved: (1) the hotel asset owner, (2) the hotel management company, and (3) the brand franchise. Large chain hotels normally own both the brand franchise and the hotel management company. Their management contract with an asset owner is typically signed for a period ranging from 30 to 60 years. The hotel management company will receive revenue and pay expenses on behalf of the owner. The owner will then receive the net profit after deducting a management fee (normally 5 percent of the total revenue). Almost every hotel has an engineer at the premise. Larger hotels may even have a team or department. The hotel operator, usually the hotel management company, will make recommendations to the asset owner about the capital expenditures that are needed for energy conservation

In contrast to residential households who may face cost of actions (see Wolak 2011), hotel chains spend large amounts of money on operating costs and are increasingly focused on reducing those costs. By consuming less water and electricity, such hotels simultaneously reduce their outgoings and increase their hotel's sustainability performance. The amount of cost savings hinges on the price of electricity in the hotel's electric utility charges. In evaluating energy efficiency investments, hotels trade off the costs of up front expenditures versus the benefits of future savings in operating costs. It is relevant to contrast such profit maximizing entities versus utility maximizing households in considering energy efficiency investments. Homeowners are more likely to be inefficient because they do not have the skills to be a sophisticated energy consumer. A household's annual electricity bill is too small for it to significantly invest in energy management skills (Hassett and Metcalf, 1993, Howarth and Sanstad, 1995). 
Commercial firms may also be less likely to suffer from behavioral biases that may otherwise lead to suboptimal investment in energy efficiency (Tietenberg, 2009). Unlike commercial electricity consumers, residential consumers often face an increasing block tariff for paying for electricity (Ito, 2014).

An important element in hotel energy consumption is the principal agent problem faced by hotel operators - hotels pay their own bills while the hotel guests face a zero marginal cost for electricity and water use. Similar to the well-known landlord-tenant split incentives problem (Gillingham et al., 2012), hotel guests have very weak financial incentives to engage in conservation. Anticipating this point, Goldstein et al. (2008) introduced the now widespread water nudges to encourage people to reuse their towels at hotels. In the case of electricity conservation, some hotels have introduced inserting key cards and other ways to encourage conservation.

\section{Methods and Data}

\section{A. Methods}

Hotels represent a standardized piece of real estate whose managers have incentives to optimize their efficiency. We explore how their electricity consumption varies across time and space. Our first empirical approach compares similar hotels located in different states while controlling for climate and occupancy conditions and the physical attributes of the hotel, such as its size and vintage. To explain the variation in the hotel chain's monthly electricity consumption, we estimate the following model for hotel $i$ in state $j$ at month $t$ :

$$
\ln k W h_{i j t}=\text { State }_{j}+\gamma \cdot \mathrm{X}_{i j t}+U_{i j t}
$$


In equation (1), the dependent variable is the log of a hotel's monthly electricity consumption. We regress this on state-fixed effects, current climate conditions (a quadratic of heating and cooling degree days), the hotel's total occupied rooms and a vector of observable attributes of the hotel; including its size, quality, service level, and vintage. We estimate equation (1) for variety of subsets of our data and we compare how our results change when we do and do not control for the average price of electricity paid by the hotel in month $j .{ }^{5}$ In all of the regressions reported in this paper, we cluster the standard errors by hotel.

We estimate equation (1) using OLS. In this regression, the error term represents the unobserved determinants of a hotel's electricity consumption in a given month. For example, a hotel's guests that month may watch more television or plug in more electronic devices. The kitchen in the hotel may serve more meals. When we estimate such cross-sectional regressions, we are implicitly assuming that sorting on unobservables is not taking place. If guests in California hotels are systematically different than guests of the same hotel chain in different states then we would recover a California-fixed effect that represents a mixture of the average hotel's energy efficiency and the electricity consumption habits of these select guests. A second challenge to interpreting our estimates of state-fixed effects as causal treatment effects would arise if the hotels the chain builds in California were different on unobserved quality attributes. ${ }^{6}$

\footnotetext{
${ }^{5}$ Increasing block tariffs are not used for commercial or industrial consumers (see Borenstein, 2009).

${ }^{6}$ In results available upon request, we also included Census demographic variables on the hotel's zip code attributes. For example, hotels in a richer part of the city might be built to higher quality. Our results are robust to controlling for such variables.
} 
The second hypothesis we test focuses on whether California's hotels have experienced greater energy efficiency progress as compared to non-California hotels. We study this by estimating equation (2). For hotel $i$ in location $j$ at time $t$ we seek to explain the variation in electricity consumption per occupied room:

$\ln \left(\frac{k \text { Wh }_{i j t}}{\text { occupied Room }_{i j t}}\right)=\alpha_{i}+\gamma_{1} \cdot \operatorname{Trend}_{i t}+\gamma_{2} \cdot \operatorname{Trend}_{i t} * X_{i j t}+\gamma_{3} *$ Climate $_{i j t}+$ $\varepsilon_{i j t}(2)$

In equation (2), the dependent variable is now the log of electricity consumption per occupied room. We view this as a measure of the hotel's productivity, comparable to gallons per mile for vehicles. We regress this on a hotel-fixed effect and climate variables. Controlling for these factors, we recover the overall time trend and we allow

the time trend to differ by geography. For example, we will test if California's time trend differs from the national average. We seek to test whether California hotels are becoming more efficient over time relative to the nation's hotels. In estimating equation (2), we are assuming that the within-hotel unobserved determinants of electricity consumption per occupied room are uncorrelated with the observables.

\section{B. Data}

Our dataset is based on one major United States hotel chain, with a global presence. It is a random sample that covers the majority of their portfolio (more than 70 percent). Our dataset includes detailed information on the electricity and natural gas usage for each hotel, as well as a large set of covariates, including: property address, square footage, number of rooms, year of construction, the hotel market quality segment, type of energy used, monthly occupancy, monthly usage and 
expenditure on electricity. The data covers the January 2007 to November 2013 period. For each hotel, climate data are matched to the nearest weather station by the data provider. We then compute heating degree days and cooling degree days for each month and for each property.

We use the data to construct the average real price per month for electricity (defined as total expenditure on electricity divided by total consumption). In our dataset, Hawaii and New York hotels face a much higher average electricity price than other states, with Hawaii at 16 cents per kWh and New York at 15 cents per kWh. California's hotels face the sixth most expensive rate, at 6.2 cents per kWh. We report our results with and without the log of real price. We view the price variable to be a control variable and do not attempt to recover a demand curve for hotel electricity consumption. The variable definitions are presented in Appendix 1 and a brief overview of the summary statistics is reported in Table 1.

[Insert Table 1 here]

\section{Results}

\section{A. Ranking State Commercial Building Energy Efficiency}

Table 2 presents six estimates of equation (1). In column (1), we report results for all hotels, including the international hotels run by the chain. We include state-fixed effects for thirteen major states: California, Ohio, Arizona, Nevada, Texas, Illinois, New Jersey, New York, Florida, Michigan, Indiana, Georgia and North Carolina, Massachusetts and Virginia. Together these states represent 70 percent of our hotel 
sample. The other hotels are included in the omitted category. A distinctive feature of our study is that we can include an international dimension because the hotel chain operates hotels in Canada, Mexico and South America. We include an international dummy for these hotels.

Controlling for climate, occupancy, and the hotel's attributes, we find that California hotels consume 24 percent less electricity as compared to the average hotel located in smaller states, consume 41 percent less electricity than international hotels (the coefficient on the international dummy is 0.17 ), and 36 percent less than Florida hotels. While California stands out as the largest (in absolute value) fixed effect, Ohio is the second most energy efficient state with a coefficient of -0.18 .

In column (2) of Table 2, we estimate the same regression, but now include the log of the real average price of electricity that the hotel paid in month $j$. Our main goal here is to analyze how robust the state-fixed effect results are to including additional control variables. The California dummy shrinks significantly, and now California and Ohio have roughly equal fixed effects - energy prices are correlated with energy performance, which partially explains California's relative efficiency. In regressions (3) and (4), we drop the international hotels and re-run the results. We find that findings are robust when we exclude these hotels.

We document that full service hotels consume much more electricity than hotels of lower quality. This result is in line with the findings of Kahn, et al. (2014), who document that higher quality commercial real estate consumes more electricity per square foot. The other explanatory variables have intuitive signs: electricity 
consumption is an increasing and concave function of hotel occupancy and square footage, and electricity consumption increases as a function of cooling degree days.

One surprising result in Table 2 is the absence of significant hotel vintage effects. Relative to the omitted category (hotels constructed before 1980), hotels built in the 1980s, 1990s, and 2000s do not have much lower levels of electricity consumption. We do find a borderline statistically significant result that hotels built in the 1990s consume 11 percent less electricity than hotels built before 1980, but these results are not persistent for more recently constructed hotels. These findings are also in line with results documented by Kahn et al. (2014) - vintage and consumption are not necessarily positively correlated in commercial real estate.

In regressions (5) and (6), we split the sample and run equation (1) for hotels built before and after the median year built (1990). We seek to test whether the California effect differs for younger versus older hotels. The results show that, for both subsamples, California's hotels are the most energy efficient, but the California "lead" over the next most energy efficient state is larger in the earlier period than the later period.

If California state policies are indeed causing the energy efficiency differential that we documented in columns (1) - (6) of Table 2, then hotels within California should be equally efficient across the state's large geographic area. To test this claim, we report additional estimates of equation (1) in columns (7) and (8) of Table 2. In this case, we partition California into four regions: the San Francisco region (CA_SF), the Los Angeles region (CA_LA), the San Diego region (CA_SD) and "other" (CA_OT). We include dummies for each of these regions and test whether the dummies' 
coefficients are equal. As shown in the additional analysis, we cannot reject this hypothesis. A joint F-test indicates that we cannot reject the hypothesis that the coefficients all are equal. This test lends support to our claim that there is a causal effect of being located in California, independent from the exact location of a hotel within the state. In column (8) of Table 2, we restrict the sample to only California hotels and re-estimate equation (1). Note that each of the California region coefficients is statistically insignificant (the omitted category is California “other”).

[Insert Table 2 here]

Mulligan and Shleifer (2005) offer a theory for why the largest states might have the most effective regulation. They argue that there is a fixed cost associated with creating regulation. This suggests that in small states such as Vermont that there would be few benefits from introducing efficiency regulation because only a handful of economic actors would be affected. In contrast, in states such as California there are thousands of commercial buildings that are affected by regulation.

\section{B. Substitution and the Energy Mix in Buildings}

The previous analysis focused on electricity consumption in buildings, but California real estate is a major consumer of natural gas. In Table 3, we introduce a new dependent variable which represents the log of a hotel's average daily carbon dioxide emissions produced. For each hotel, we know its NERC region emissions factor and we use this information to calculate $\mathrm{Y}=\log ((\mathrm{kwh} / 1000) * \mathrm{co} 2$ emissions factor $+11.7^{*}$ therms). This equation uses information on each hotel's electricity 
consumption, natural gas consumption and the hotel's NERC region emissions factor to calculate the log of pounds of carbon dioxide released by each hotel.

This is the dependent variable in Table 3's columns (1) and (2). The results for the control variables are quite similar to those reported in Table. California continues to have a negative and statistically significant coefficient relative to small states but is no longer the "greenest" state. Massachusetts and New York have more negative coefficients. In column (2), we include the log of average energy cost. Average energy cost is computed as the total expense divided by total usage. In column (3), we switch the dependent variable to measure the log of average daily total energy BTU per hotel. ${ }^{7}$ We find that California has a negative coefficient of -.09 but it is less green than Ohio, North Carolina, and Texas.

\section{Testing for Differentials in Energy Efficiency Trends}

Environmental groups such as the National Resources Defense Council have marveled that California's economic productivity per kWh of electricity consumed has improved over 50 percent in real dollars since 1980. In contrast, the rest of the US has only improved by 15 percent. $^{8}$ A standard environmental accounting approach would seek to measure how much of this differential is due to shifting composition effects versus actual technique differentials between states.

We estimate equation (2) to study the relative progress in the energy efficiency of California as compared to the rest of the nation. Table 3 presents the results.

\footnotetext{
7 This is defined as $\log (($ electricity consumption+natural gas in therms*100000/3413)/curr_days).

${ }^{8}$ See http://switchboard.nrdc.org/blogs/smartinez/california_restores_its_energy.html and http://docs.nrdc.org/energy/files/ene_10030901a.pdf.
} 
Estimates of equation (2) allow us to focus on testing spatial hypotheses related to how the technique effect is changing in different states over time. The dependent variable is the logarithm of monthly hotel electricity consumption per occupied room. Hotel electricity consumption per occupied room offers a standardized comparison metric similar to gallons per mile for vehicles or the industrial sector's carbon intensity (carbon emissions per dollar of value added).

A more efficient hotel should consume less electricity per occupied room. We control for hotel fixed effects and examine the monthly time trend. The average domestic hotel has no change in its energy efficiency while the average international hotel is consuming 9.6 percent $\left(0.008^{*} 12\right)$ more electricity per year, on average. In contrast, we estimate a negative and statistically significant trend for California's hotels equal to 4.8 percent per year. While our data set covers the years 2007 to the end of 2013, this effect would add up to a large increase in energy efficiency over time. In Summer 2014, President Obama committed the U.S to reduce its greenhouse gas emissions, and part of that plan is a 1.5 percent per year improvement in energy efficiency. Our estimate of the California time trend is much larger.

In column 2 of Table 4 we introduce another explanatory variable, which is an interaction between the hotel's county's share of the electorate that voted for John Kerry (the Democrat) in 2004, interacted with the time trend. This variable allows us to test for whether the California negative trend is due to the state's liberal leaning. To our surprise this interaction term is positive (indicating that hotels in more liberal counties actually increase their electricity consumption over time relative to Conservative counties), but the California dummy is still negative and statistically 
significant. Recall that this time trend is identified based on within hotel variation in electricity consumption per occupied room between the years 2007 and 2013. Understanding the causes of this differential time trend merits future empirical research.

In columns (3) and (4) we again include the log of the real average price of electricity that the hotel paid in month $j$. The coefficients indicate that electricity prices are strongly correlated with over-time progress in the reduction of electricity consumption. The results for California remain significant, and economically large, with an average annual reduction in electricity consumption of 3.6 percent (over the 2007-2013 period). In column (5), we switch the dependent variable to be the log of a hotel's total energy consumption. We find that California does not have a differential trend than the rest of the nation but when we switch the dependent variable to be the $\log$ of the hotel's total carbon dioxide emissions, California again has a sharply negative trend of -.007 per month versus the rest of the nation at -.003 per month. Both of these coefficients and their differential are statistically significant.

\section{Conclusion}

While residential electricity consumption patterns have been well studied (see, for example, Chong, 2012, Jacobsen and Kotchen, 2013), we know very little about how commercial buildings, occupied by some of the major corporations, perform over time. Commercial real estate features owners are typically less heterogeneous and likely to be more responsive and better trained to use energy efficiently relative to residential electricity consumers. 
This paper exploits a large random sample of hotels from a major global hotel chain to explore both spatial and temporal variation in hotel electricity consumption. The hotel capital stock is an important component of the commercial real estate stock. Hotels consume electricity, with guests demanding basic services such as lighting, comfort, entertainment and safety. As profit-maximizing entities, hotels have strong incentives to invest in energy efficiency in order to equate the expected present discounted savings in operating expenses with the marginal cost of achieving these gains.

At a point in time, the chain's hotels face different climate conditions, occupancy rates, and electricity prices. Controlling for these factors, we focus on recovering statefixed effects. California stands out as the most energy efficient state, but it is only slightly more energy efficient than the next closest states such as Ohio and Arizona. Based on regressions where we include hotel fixed effects, California's hotels feature a much larger decline in electricity consumption per occupied room than the rest of the nation. California's hotels are reducing their electricity consumption per occupied room by roughly 5 percent per year during our sample period covering 2007 to 2013 while domestic hotels from the same chain not located in California are experiencing no measurable energy efficiency progress. The within-hotel evidence is consistent with the claim that California energy efficiency policy is an important determinant of efficiency progress.

Of course, our conclusions are based on a rather crude measure of "policy" and more detailed insight into the drivers of reductions in consumption is desirable. Data from the California Electricity Commission (CEC) are useful for establishing changes 
to the building code during the calendar years of our study. ${ }^{9}$ These documents indicate that California's commercial building code tightened in the years 2001, 2005, 2008, and 2013. If we had data on a sufficiently large number of hotels in California, we could introduce an event study approach to test for whether these code changes yield statistically significant reductions in electricity consumption. We do not have enough hotels to implement this approach. The CEC's records indicate a whole host of changes concerning: the roof, insulation, the building envelope, water heating, cooling and lighting and other features such that it would be quite difficult to tease out the most important causes of electricity productivity gains. ${ }^{10}$ Future research should address the exact impact of these policy changes in more detail, ideally using monthly hotel data rather than higher frequency such as 15 minute interval data.

\footnotetext{
${ }^{9}$ See http://www.energy.ca.gov/title 24/.

${ }^{10}$ See http://www.energy.ca.gov/title24/standards archive/ and http://www.energy.ca.gov/2008publications/CEC-400-2008017/rev1_chapters/NRCM_Chapter_1_Introduction.pdf
} 


\section{References}

Allcott, Hunt. 2011. "Social Norms and Energy Conservation." Journal of Public Economics, 95(5), 1082-95.

Aroonruengsawat, Anin and Maximillian Auffhammer. 2011. "The Impact of Buildings Codes on Residential Electricity Consumption," G. Libecap and R. H. Steckel, The Economics of Climate Change: Adaptations Past and Present. Chicago: University of Chicago Press,

Becker, Randy and Vernon Henderson. 2000. "Effects of Air Quality Regulations on Polluting Industries." Journal of Political Economy, 108(2), 379-421.

Borenstein, Severin. 2009. "To What Electricity Price Do Consumers Respond? Residential Demand Elasticity under Increasing-Block Pricing," Working Paper. UC Berkeley:

Brounen, Dirk; Nils Kok and John M. Quigley. 2012. "Residential Energy Use and Conservation: Economics and Demographics." European Economic Review, 56(5), 931-45.

Chong, Howard. 2012. "Building Vintage and Electricity Use: Old Homes Use Less Electricity in Hot Weather." European Economic Review, 56(5), 906-30.

Gillingham, Kenneth; Matthew Harding and David Rapson. 2012. "Split Incentives in Residential Energy Consumption." Energy Journal, 33(2), 37-62.

Goldstein, Noah J.; Robert Cialdini and Vladas Griskevicius. 2008. "A Room with a Viewpoint: Using Social Norms to Motivate Environmental Conservation in Hotels." Journal of Consumer Research, 35(3), 472-82.

Hassett, Kevin A. and Gilbert E. Metcalf. 1993. "Energy Conservation Investment: Do Consumers Discount the Future Correctly?" Energy Policy, 21(6), 710-16.

Holmes, Thomas J. 1998. "The Effect of State Policies on the Location of Manufacturing: Evidence from State Borders." Journal of Political Economy, 106(4), 667-705.

Howarth, Richard B. and Alan H. Sanstad. 1995. "Discount Rates and Energy Efficiency." Contemporary Economic Policy, 13(3), 101-09.

Ito, Koichiro. 2014. "Do Consumers Respond to Marginal or Average Price? Evidence from Nonlinear Electricity Pricing." American Economic Review, 140(2), 537-63.

Jacobsen, Grant D. and Matthew J. Kotchen. 2013. "Are Building Codes Effective at Saving Energy? Evidence from Residential Billing Data in Florida." Review of Economics and Statistics, 95(1), 34-49. 
Kahn, Matthew E.; Nils Kok and John M. Quigley. 2014. "Carbon Emissions from the Commercial Building Sector: The Role of Climate, Quality, and Incentives." Journal of Public Economics, 113, 1-12.

Levinson, Arik. 2014. "California Energy Efficiency: Lessons for the Rest of the World, or Not?" Journal of Economic Behavior \& Organization, 107, 269-89.

Levinson, Arik and Scott Niemann. 2004. "Energy Use by Apartment Tenants When Landlords Pay for Utilities." Resource and Energy Economics, 26(1), 51-75.

Michael, Robert T. and Gary S. Becker. 1973. "On the New Theory of Consumer Behavior." Swedish Journal of Economics, 75(4), 378-96.

Mulligan, Casey and Andrei Shleifer. 2005. "The Extent of the Market and the Supply of Regulation." Quarterly Journal of Economics, 120(4), 1445-73.

Reiss, Peter C. and Matthew W. White. 2005. "Household Electricity Demand, Revisited." Review of Economic Studies, 72(3), 853-83.

Tietenberg, Tom. 2009. "Reflections-Energy Efficiency Policy: Pipe Dream or Pipeline to the Future?" Review of Environmental Economics and Policy, 3(2), 304-20.

Wolak, Frank. 2011. "Do Residential Customers Respond to Hourly Prices?

Evidence from a Dynamic Pricing Experiment." American Economic Review, 101(3), 83-87. 


\section{Appendix 1 Variable Definitions}

\begin{tabular}{|c|c|}
\hline Variable & Definition \\
\hline Usage_Curr_Elec & Electricity usage in the current month (kWh) \\
\hline Usage_Curr_Gas & Natural gas usage in the current month (MBTU) \\
\hline Unit Cost_Curr & Unit monthly cost of electricity \\
\hline Occupied Rooms & Number of occupied rooms per month \\
\hline Y1 & Natural logarithm of daily average electricity usage in the current month \\
\hline Y2 & Natural logarithm of electricity usage per occupied room in the current month \\
\hline Y3 & Natural logarithm of total energy usage per occupied room in the current month \\
\hline Electricity Share & $\begin{array}{l}\text { Share of electricity to total energy expenditure per occupied room in the current } \\
\text { month }\end{array}$ \\
\hline Daily Energy (log) & Natural logarithm of daily average total energy expenditure in the current month \\
\hline CO2 Production (log) & Natural logarithm of average total CO2 production in the current month \\
\hline Occupancy & Average occupancy ratio for the current month \\
\hline HDD_K & $\begin{array}{l}\text { Heating degree days (thousands), defined as total number of degree and days } \\
\text { with temperature lower than } 65 \mathrm{~F} \text { in the current month }\end{array}$ \\
\hline CDD_K & $\begin{array}{l}\text { Cooling degree days (thousands), defined as total number of degree and days } \\
\text { with temperature higher than } 65 \mathrm{~F} \text { in the current month }\end{array}$ \\
\hline SQFT_M & Square footage (millions) \\
\hline Energy Cost (log) & Natural logarithm of electricity expense for the current month \\
\hline Ybuilt & Year built \\
\hline Trend & Jan. 2007 defines trend=1 \\
\hline Age & Building age (month) \\
\hline Built80 & Dummy variable for hotels built in 80 's \\
\hline Built90 & Dummy variable for hotels built in 90's \\
\hline Built00 & Dummy variable for hotels built after 2000 \\
\hline Full Service (1=Yes) & Full service hotels, dummy variable for hotel quality, $1=$ yes \\
\hline Alternative $(1=$ Yes $)$ & Alternative energy available at the hotel, dummy variable, $1=$ yes \\
\hline International (1=Yes) & International hotels, dummy variable, $1=$ yes \\
\hline CA & Dummy variable for California state \\
\hline $\mathrm{OH}$ & Dummy variable for Ohio state \\
\hline AZ & Dummy variable for Arizona state \\
\hline NC & Dummy variable for North Carolina state \\
\hline MA & Dummy variable for Massachusetts state \\
\hline NV & Dummy variable for Nevada state \\
\hline $\mathrm{TX}$ & Dummy variable for Texas state \\
\hline IL & Dummy variable for Illinois state \\
\hline NY & Dummy variable for New York state \\
\hline MI & Dummy variable for Michigan state \\
\hline NJ & Dummy variable for New Jersey state \\
\hline IN & Dummy variable for Indiana state \\
\hline VA & Dummy variable for Virginia state \\
\hline GA & Dummy variable for Georgia state \\
\hline MD & Dummy variable for Maryland state \\
\hline FL & Dummy variable for Florida state \\
\hline CA_SF & Dummy variable for San Francisco Bay Area in California \\
\hline CA_LA & Dummy variable for Los Angeles and Orange County in California \\
\hline CA_SD & Dummy variable for San Diego in California \\
\hline CA_OT & Dummy variable for Other Area in California \\
\hline
\end{tabular}


Table 1 Summary Statistics (51,544 observations)

\begin{tabular}{|c|c|c|c|c|c|}
\hline Variable & Mean & Median & St. Dev. & Min & Max \\
\hline Usage_Curr_Elec & $288,333.38$ & 120,639 & $386,385.53$ & 173.00 & $5,725,663$ \\
\hline Usage_Curr_Gas & $64,247.70$ & 417 & $394,424.40$ & 0 & $6,412,140$ \\
\hline Unit Cost_Curr & 0.107 & 0.10 & 0.106 & 0.01 & 14.33 \\
\hline Occupied Rooms & $5,348.38$ & 3,404 & $5,145.22$ & 124 & 71,220 \\
\hline Y1 & 8.630 & 8.286 & 0.954 & 1.721 & 12.126 \\
\hline Y2 & 3.713 & 3.646 & 0.538 & -2.093 & 6.897 \\
\hline Y3 & 4.220 & 4.090 & 0.549 & -3.172 & 7.972 \\
\hline Electricity Share & 0.803 & 0.824 & 0.112 & 0.000 & 1.000 \\
\hline Daily Energy (log) & 0.461 & 0.451 & 0.097 & 0.223 & 15.316 \\
\hline Occupancy & 0.690 & 0.703 & 0.136 & 0.038 & 1.000 \\
\hline HDD_K & 0.286 & 0.140 & 0.343 & 0.000 & 1.756 \\
\hline CDD_K & 0.148 & 0.040 & 0.199 & 0.000 & 1.033 \\
\hline SQFT_M & 0.203 & 0.090 & 0.248 & 0.000 & 4.066 \\
\hline Energy Cost (log) & -2.296 & -2.303 & 0.342 & -4.605 & 5.574 \\
\hline Ybuilt & 1990 & 1990 & 13.136 & 1906 & 2012 \\
\hline Trend & 39.866 & 40 & 21.807 & 1 & 83 \\
\hline Age & 19.704 & 20 & 13.197 & 0 & 107 \\
\hline Built80 & 0.423 & 0 & 0.494 & 0 & 1 \\
\hline Built90 & 0.297 & 0 & 0.458 & 0 & 1 \\
\hline Built00 & 0.203 & 0 & 0.402 & 0 & 1 \\
\hline Full Service (1=Yes) & 0.329 & 0 & 0.470 & 0 & 1 \\
\hline Alternative (1=Yes) & 0.047 & 0 & 0.213 & 0 & 1 \\
\hline International (1=Yes) & 0.044 & 0 & 0.204 & 0 & 1 \\
\hline CA & 0.135 & 0 & 0.342 & 0 & 1 \\
\hline $\mathrm{OH}$ & 0.041 & 0 & 0.196 & 0 & 1 \\
\hline AZ & 0.031 & 0 & 0.173 & 0 & 1 \\
\hline NC & 0.028 & 0 & 0.165 & 0 & 1 \\
\hline MA & 0.036 & 0 & 0.186 & 0 & 1 \\
\hline NV & 0.012 & 0 & 0.110 & 0 & 1 \\
\hline TX & 0.075 & 0 & 0.264 & 0 & 1 \\
\hline IL & 0.043 & 0 & 0.203 & 0 & 1 \\
\hline NY & 0.034 & 0 & 0.182 & 0 & 1 \\
\hline MI & 0.023 & 0 & 0.151 & 0 & 1 \\
\hline NJ & 0.033 & 0 & 0.178 & 0 & 1 \\
\hline IN & 0.005 & 0 & 0.073 & 0 & 1 \\
\hline VA & 0.058 & 0 & 0.233 & 0 & 1 \\
\hline GA & 0.063 & 0 & 0.244 & 0 & 1 \\
\hline MD & 0.037 & 0 & 0.190 & 0 & 1 \\
\hline FL & 0.080 & 0 & 0.271 & 0 & 1 \\
\hline CA_SF & 0.030 & 0 & 0.172 & 0 & 1 \\
\hline CA_LA & 0.056 & 0 & 0.229 & 0 & 1 \\
\hline CA_SD & 0.016 & 0 & 0.125 & 0 & 1 \\
\hline CA_OT & 0.032 & 0 & 0.175 & 0 & 1 \\
\hline
\end{tabular}

Notes: The table report summary statistics for variables used in the analysis. Please refer to the Appendix for variable definitions. 
Table 2

Regression Results

Hotel Electricity Consumption and the California Effect

\begin{tabular}{|c|c|c|c|c|c|c|c|c|}
\hline & $(1)$ & $(2)$ & (3) & (4) & (5) & (6) & $(7)$ & $(8)$ \\
\hline \multirow[t]{2}{*}{ Occupancy } & $0.560 * * *$ & $0.450 * *$ & 0.320 & 0.230 & 0.140 & $0.470 * *$ & $0.440 * *$ & -0.560 \\
\hline & {$[0.212]$} & {$[0.216]$} & {$[0.294]$} & [0.291] & {$[0.378]$} & [0.239] & [0.215] & [0.509] \\
\hline \multirow[t]{2}{*}{ Occupancy $^{2}$} & -0.130 & -0.030 & 0.070 & 0.140 & 0.230 & -0.090 & -0.020 & $0.640^{*}$ \\
\hline & [0.163] & [0.158] & {$[0.226]$} & [0.215] & [0.291] & [0.167] & [0.133] & {$[0.356]$} \\
\hline \multirow[t]{2}{*}{ HDD_K } & 0.130 & 0.120 & $0.220^{* * *}$ & $0.210 * * *$ & $0.210^{*}$ & -0.080 & 0.130 & $-0.410 * * *$ \\
\hline & {$[0.103]$} & {$[0.094]$} & {$[0.053]$} & {$[0.053]$} & [0.115] & {$[0.131]$} & {$[0.098]$} & [0.106] \\
\hline \multirow[t]{2}{*}{ CDD_K } & $0.870^{* * *}$ & $0.860^{* * *}$ & $1.050^{* * *}$ & $1.040^{* * *}$ & $0.970^{* * *}$ & $0.620^{* * *}$ & $0.860^{* * *}$ & $0.540^{* * *}$ \\
\hline & [0.178] & [0.171] & {$[0.076]$} & {$[0.075]$} & [0.192] & [0.218] & [0.171] & [0.194] \\
\hline \multirow[t]{2}{*}{ HDD_K ${ }^{2}$} & $0.250 * * *$ & $0.250^{* * *}$ & $0.190^{* * *}$ & $0.190 * * *$ & $0.140^{*}$ & $0.450^{* * *}$ & $0.240^{* * *}$ & $0.670^{* * *}$ \\
\hline & {$[0.068]$} & {$[0.068]$} & {$[0.043]$} & {$[0.043]$} & {$[0.079]$} & [0.089] & {$[0.066]$} & [0.183] \\
\hline \multirow[t]{2}{*}{ CDD_K ${ }^{2}$} & -0.260 & -0.230 & $-0.430 * * *$ & $-0.420 * * *$ & -0.330 & 0.020 & -0.220 & 0.190 \\
\hline & [0.197] & [0.19] & {$[0.093]$} & [0.093] & {$[0.21]$} & {$[0.222]$} & [0.183] & [0.292] \\
\hline \multirow[t]{2}{*}{ SQFT_M } & $2.90 * * *$ & $2.860^{* * *}$ & $2.930 * * *$ & $2.920 * * *$ & $2.330 * * *$ & $4.370^{* * *}$ & $2.860 * * *$ & $4.010^{* * *}$ \\
\hline & [0.298] & [0.291] & [0.305] & [0.303] & [0.295] & [0.325] & [0.291] & [0.444] \\
\hline \multirow[t]{2}{*}{ SQFT_M ${ }^{2}$} & $-0.820 * * *$ & $-0.810 * * *$ & $-0.830 * * *$ & $-0.830 * * *$ & $-0.530 * * *$ & $-1.70 * * *$ & $-0.80 * * *$ & $-1.510 * * *$ \\
\hline & {$[0.166]$} & [0.164] & {$[0.171]$} & {$[0.171]$} & [0.135] & {$[0.21]$} & [0.162] & [0.249] \\
\hline \multicolumn{9}{|l|}{ Age } \\
\hline \multirow[t]{2}{*}{ 1980-1990 } & -0.050 & -0.030 & -0.060 & -0.070 & -0.080 & & -0.030 & $-0.140 *$ \\
\hline & {$[0.056]$} & [0.058] & [0.053] & [0.057] & [0.057] & & {$[0.056]$} & [0.082] \\
\hline \multirow[t]{2}{*}{$1990-2000$} & $-0.110 *$ & -0.080 & $-0.120 * *$ & $-0.130 * *$ & & & -0.080 & -0.10 \\
\hline & [0.065] & [0.058] & [0.057] & [0.057] & & & [0.057] & [0.092] \\
\hline \multirow{2}{*}{$>2000$} & 0.010 & 0.030 & 0.020 & 0.010 & & $0.070^{* *}$ & 0.030 & -0.030 \\
\hline & [0.067] & [0.058] & [0.059] & [0.059] & & [0.03] & {$[0.06]$} & [0.107] \\
\hline \multirow{2}{*}{$\begin{array}{l}\text { Full Service } \\
(1=Y e s)\end{array}$} & $0.960 * * *$ & $0.980^{* * *}$ & $0.960 * * *$ & $0.950 * * *$ & $1.030 * * *$ & $0.790^{* * *}$ & $0.980^{* * *}$ & $0.820^{* * *}$ \\
\hline & {$[0.068]$} & [0.065] & {$[0.067]$} & {$[0.066]$} & {$[0.08]$} & {$[0.072]$} & [0.065] & [0.101] \\
\hline \multirow{2}{*}{$\begin{array}{l}\text { Alternative } \\
\text { (1=Yes) }\end{array}$} & -0.050 & -0.060 & -0.070 & -0.070 & -0.060 & -0.030 & -0.050 & 0.020 \\
\hline & [0.067] & [0.075] & [0.07] & [0.074] & [0.092] & [0.107] & [0.067] & [0.133] \\
\hline \multirow{2}{*}{$\begin{array}{l}\text { International } \\
(1=Y e s)\end{array}$} & $0.170^{*}$ & $0.160^{*}$ & & & 0.10 & $0.180 * *$ & $0.160^{*}$ & \\
\hline & [0.091] & [0.083] & & & [0.192] & [0.083] & [0.082] & \\
\hline \multicolumn{9}{|l|}{ State } \\
\hline \multirow[t]{2}{*}{ CA } & $-0.240 * * *$ & $-0.180 * * *$ & $-0.230 * * *$ & $-0.160 * * *$ & $-0.190 * * *$ & $-0.170 * * *$ & & \\
\hline & [0.031] & [0.038] & [0.03] & {$[0.04]$} & [0.056] & [0.052] & & \\
\hline \multirow[t]{2}{*}{$\mathrm{OH}$} & $-0.180 * * *$ & $-0.170 * * *$ & $-0.170 * * *$ & $-0.160 * * *$ & -0.130 & $-0.160 * *$ & $-0.170 * * *$ & \\
\hline & {$[0.063]$} & {$[0.062]$} & {$[0.062]$} & {$[0.061]$} & [0.079] & [0.077] & [0.062] & \\
\hline \multirow[t]{2}{*}{$\mathrm{AZ}$} & $-0.10 * *$ & $-0.10^{* *}$ & $-0.090 * *$ & $-0.090 *$ & -0.140 & $-0.120 *$ & $-0.10 * *$ & \\
\hline & [0.048] & [0.049] & [0.045] & [0.049] & [0.086] & [0.071] & [0.05] & \\
\hline \multirow[t]{2}{*}{ NC } & $-0.080 * *$ & $-0.120 * * *$ & $-0.070 * *$ & $-0.130 * * *$ & $-0.130 * *$ & $-0.110^{*}$ & $-0.120^{* * *}$ & \\
\hline & [0.039] & [0.038] & [0.035] & {$[0.04]$} & [0.051] & [0.059] & [0.038] & \\
\hline MA & -0.070 & -0.010 & -0.070 & 0.010 & 0.040 & -0.060 & -0.010 & \\
\hline & {$[0.066]$} & [0.067] & [0.065] & [0.111] & [0.125] & [0.079] & [0.063] & \\
\hline NV & -0.070 & -0.060 & -0.060 & -0.050 & -0.020 & -0.080 & -0.060 & \\
\hline & [0.119] & [0.115] & {$[0.111]$} & [0.119] & [0.118] & [0.145] & [0.115] & \\
\hline $\mathrm{TX}$ & -0.060 & -0.040 & -0.060 & -0.030 & -0.040 & -0.040 & -0.040 & \\
\hline & [0.039] & {$[0.042]$} & [0.039] & [0.038] & {$[0.06]$} & [0.061] & [0.042] & \\
\hline IL & -0.060 & -0.070 & -0.060 & -0.080 & -0.070 & $-0.120 *$ & -0.070 & \\
\hline & {$[0.058]$} & {$[0.061]$} & [0.057] & [0.063] & [0.081] & [0.072] & [0.061] & \\
\hline NY & -0.040 & 0.050 & -0.040 & 0.080 & 0.020 & 0.070 & 0.050 & \\
\hline & [0.057] & {$[0.057]$} & [0.055] & [0.062] & {$[0.087]$} & [0.095] & {$[0.058]$} & \\
\hline
\end{tabular}


Table 2 (Continued)

\begin{tabular}{|c|c|c|c|c|c|c|c|c|}
\hline & (1) & (2) & (3) & (4) & (5) & (6) & (7) & (8) \\
\hline \multirow[t]{2}{*}{ MI } & -0.040 & -0.030 & -0.030 & -0.020 & 0.000 & -0.180 & -0.030 & \\
\hline & [0.103] & [0.111] & {$[0.086]$} & [0.077] & [0.000] & [0.196] & [0.111] & \\
\hline \multirow[t]{2}{*}{ NJ } & -0.010 & 0.060 & -0.010 & 0.070 & 0.020 & 0.110 & 0.060 & \\
\hline & [0.091] & [0.069] & [0.048] & [0.067] & {$[0.100]$} & [0.089] & [0.069] & \\
\hline \multirow[t]{2}{*}{ IN } & 0.040 & 0.010 & 0.050 & 0.020 & -0.060 & $0.070 * *$ & 0.010 & \\
\hline & [0.043] & [0.033] & [0.045] & [0.053] & [0.079] & [0.032] & [0.032] & \\
\hline \multirow[t]{2}{*}{ VA } & 0.060 & 0.040 & 0.050 & 0.030 & $0.090^{*}$ & -0.010 & 0.040 & \\
\hline & [0.061] & [0.063] & {$[0.054]$} & {$[0.06]$} & {$[0.052]$} & {$[0.125]$} & [0.063] & \\
\hline \multirow[t]{2}{*}{ GA } & 0.060 & 0.060 & 0.060 & 0.060 & 0.070 & 0.050 & 0.060 & \\
\hline & [0.046] & [0.043] & [0.046] & [0.043] & [0.053] & [0.083] & [0.043] & \\
\hline \multirow[t]{2}{*}{ MD } & 0.060 & $0.110^{* *}$ & 0.060 & $0.130 * *$ & $0.140 *$ & 0.080 & $0.110^{* *}$ & \\
\hline & {$[0.046]$} & [0.049] & [0.048] & {$[0.052]$} & {$[0.076]$} & {$[0.061]$} & [0.049] & \\
\hline \multirow[t]{2}{*}{ FL } & $0.120 * *$ & $0.140 * * *$ & $0.110^{* *}$ & $0.130 * * *$ & 0.050 & $0.210 * * *$ & & \\
\hline & [0.051] & {$[0.052]$} & {$[0.05]$} & {$[0.05]$} & [0.063] & {$[0.062]$} & & \\
\hline CA_SF & & & & & & & $\begin{array}{l}-0.220 * * * \\
{[0.057]}\end{array}$ & $\begin{array}{l}-0.040 \\
{[0.059]}\end{array}$ \\
\hline \multirow[t]{2}{*}{ CA_SD } & & & & & & & $-0.20 * * *$ & -0.020 \\
\hline & & & & & & & [0.063] & [0.083] \\
\hline \multirow[t]{2}{*}{ CA_LA } & & & & & & & $-0.170 * * *$ & -0.010 \\
\hline & & & & & & & {$[0.046]$} & [0.043] \\
\hline CA_OT & & & & & & & $\begin{array}{l}-0.160 * * * \\
{[0.06]}\end{array}$ & \\
\hline \multirow{2}{*}{$\begin{array}{l}\text { Energy Cost } \\
(\log )\end{array}$} & & $-0.140 * * *$ & & $-0.180^{* * *}$ & $-0.160 *$ & $-0.140 * *$ & $-0.140 * * *$ & 0.050 \\
\hline & & {$[0.051]$} & & {$[0.055]$} & [0.082] & {$[0.058]$} & {$[0.051]$} & [0.091] \\
\hline \multirow[t]{2}{*}{ Intercept } & $7.370^{* * *}$ & $7.040 * * *$ & $7.410^{* * *}$ & $7.020 * * *$ & $7.170^{* * *}$ & $6.890 * * *$ & $7.040 * * *$ & 7.660 *** \\
\hline & [0.107] & [0.167] & {$[0.121]$} & {$[0.174]$} & {$[0.253]$} & {$[0.166]$} & {$[0.167]$} & [0.292] \\
\hline $\mathrm{R}^{2}$ & 0.876 & 0.879 & 0.882 & 0.883 & 0.901 & 0.859 & 0.879 & 0.952 \\
\hline Observations & 51,306 & 51,210 & 49,251 & 49,228 & 25,572 & 25,638 & 51,210 & 6,887 \\
\hline Clusters & 766 & 764 & 722 & 721 & 360 & 404 & 764 & 100 \\
\hline
\end{tabular}

Notes: The table reports the estimation results of equation (1). The dependent variable is the natural logarithm of daily average electricity usage in the current month. Column (8) only includes hotels located in California. Refer to the Appendix for variable definitions. Standard errors in brackets are clustered by hotel. ${ }^{* * *} \mathrm{p}<0.01,{ }^{* *} \mathrm{p}<0.05,{ }^{*} \mathrm{p}<0.1$ 
Table 3

Regression Results

Energy Consumption Including Electricity and Natural Gas

\begin{tabular}{|c|c|c|c|}
\hline & $(1)$ & $(2)$ & (3) \\
\hline \multirow[t]{2}{*}{ Occupancy } & 0.290 & 0.170 & -0.080 \\
\hline & {$[0.264]$} & {$[0.258]$} & [0.333] \\
\hline \multirow[t]{2}{*}{ Occupancy $^{2}$} & 0.070 & 0.180 & 0.390 \\
\hline & {$[0.200]$} & [0.209] & [0.247] \\
\hline \multirow[t]{2}{*}{ HDD_K } & $0.400^{* * *}$ & $0.400^{* * *}$ & $0.590^{* * *}$ \\
\hline & [0.051] & {$[0.051]$} & [0.056] \\
\hline \multirow[t]{2}{*}{ CDD_K } & $0.970^{* * *}$ & $0.960^{* * *}$ & $0.620^{* * *}$ \\
\hline & [0.068] & {$[0.068]$} & [0.073] \\
\hline \multirow[t]{2}{*}{ HDD_K ${ }^{2}$} & $0.140 * * *$ & $0.120^{* * *}$ & 0.050 \\
\hline & {$[0.043]$} & [0.039] & {$[0.041]$} \\
\hline \multirow[t]{2}{*}{ CDD_K ${ }^{2}$} & $-0.490 * * *$ & $-0.480 * * *$ & $-0.360 * * *$ \\
\hline & [0.077] & [0.077] & {$[0.081]$} \\
\hline \multirow[t]{2}{*}{ SQFT_M } & $3.510^{* * *}$ & $3.480^{* * *}$ & $2.730^{* * *}$ \\
\hline & {$[0.403]$} & [0.399] & {$[0.407]$} \\
\hline \multirow[t]{2}{*}{ SQFT_M ${ }^{2}$} & $-0.880^{* * *}$ & $-0.860 * * *$ & $-0.790 * * *$ \\
\hline & [0.252] & {$[0.248]$} & [0.252] \\
\hline \multicolumn{4}{|l|}{ Age } \\
\hline \multirow[t]{2}{*}{$1980-1990$} & $-0.100 *$ & $-0.110 * *$ & -0.060 \\
\hline & {$[0.053]$} & [0.054] & [0.058] \\
\hline \multirow[t]{2}{*}{$1990-2000$} & $-0.180 * * *$ & $-0.200^{* * *}$ & $-0.170^{* * *}$ \\
\hline & {$[0.060]$} & {$[0.062]$} & [0.065] \\
\hline \multirow[t]{2}{*}{$>2000$} & -0.02 & -0.03 & 0.01 \\
\hline & [0.065] & [0.055] & [0.100] \\
\hline \multirow[t]{2}{*}{ Full Service (1=yes) } & $0.940 * * *$ & $0.920^{* * *}$ & $1.090^{* * *}$ \\
\hline & [0.068] & {$[0.067]$} & {$[0.077]$} \\
\hline \multirow[t]{2}{*}{ Alternative (1=yes) } & -0.11 & -0.11 & $-0.240^{* * *}$ \\
\hline & {$[0.076]$} & {$[0.080]$} & [0.090] \\
\hline \multirow[t]{2}{*}{ International (1=yes) } & & & $0.410 *$ \\
\hline & & & {$[0.238]$} \\
\hline \multicolumn{4}{|l|}{ State } \\
\hline \multirow[t]{2}{*}{ CA } & $-0.390 * * *$ & $-0.280 * * *$ & $-0.090 * *$ \\
\hline & [0.034] & [0.045] & [0.035] \\
\hline \multirow[t]{2}{*}{$\mathrm{OH}$} & -0.100 & -0.090 & $-0.190 * *$ \\
\hline & {$[0.067]$} & {$[0.068]$} & [0.077] \\
\hline \multirow[t]{2}{*}{$\mathrm{AZ}$} & $-0.300 * * *$ & $-0.280^{* * *}$ & 0.01 \\
\hline & {$[0.040]$} & {$[0.039]$} & [0.043] \\
\hline \multirow[t]{2}{*}{ NC } & $-0.070^{*}$ & $-0.140 * * *$ & $-0.110 * * *$ \\
\hline & [0.041] & {$[0.040]$} & [0.042] \\
\hline \multirow[t]{2}{*}{ MA } & $-0.550 * * *$ & $-0.440 * * *$ & -0.080 \\
\hline & {$[0.082]$} & {$[0.087]$} & {$[0.085]$} \\
\hline \multirow[t]{2}{*}{ NV } & $-0.310 * * *$ & $-0.290 * * *$ & 0.010 \\
\hline & [0.097] & [0.100] & [0.100] \\
\hline \multirow[t]{2}{*}{$\mathrm{TX}$} & $-0.140 * * *$ & $-0.090 * *$ & $-0.110 * * *$ \\
\hline & [0.043] & [0.042] & [0.041] \\
\hline IL & -0.040 & -0.050 & -0.020 \\
\hline & [0.057] & {$[0.052]$} & [0.063] \\
\hline NY & $-0.510 * * *$ & $-0.340 * * *$ & -0.010 \\
\hline & [0.065] & [0.071] & {$[0.077]$} \\
\hline
\end{tabular}




\begin{tabular}{lccc}
\hline & $(1)$ & $(2)$ & $(3)$ \\
\hline MI & 0.100 & 0.120 & 0.050 \\
& {$[0.082]$} & {$[0.081]$} & {$[0.086]$} \\
NJ & 0.050 & $0.170^{* *}$ & 0.000 \\
& {$[0.068]$} & {$[0.076]$} & {$[0.000]$} \\
IN & $0.170^{* * *}$ & $0.130^{* * *}$ & $0.190^{* * *}$ \\
& {$[0.038]$} & {$[0.042]$} & {$[0.040]$} \\
VA & 0.030 & & \\
& {$[0.060]$} & & \\
GA & 0.020 & 0.030 & -0.010 \\
& {$[0.038]$} & {$[0.039]$} & {$[0.032]$} \\
MD & $0.110^{* *}$ & $0.210^{* * *}$ & 0.060 \\
& {$[0.048]$} & {$[0.055]$} & {$[0.051]$} \\
FL & 0.050 & $0.080^{*}$ & 0.070 \\
& {$[0.045]$} & {$[0.045]$} & {$[0.058]$} \\
Room Size & $-388.320^{* * *}$ & $-383.490^{* * *}$ & \\
& {$[78.290]$} & {$[75.490]$} & \\
Energy Cost (log) & & $-0.240^{* * *}$ & \\
& & {$[0.056]$} & \\
Intercept & $11.310^{* * *}$ & $10.750^{* * *}$ & $8.080^{* * *}$ \\
& {$[0.112]$} & {$[0.172]$} & {$[0.140]$} \\
& & & \\
\hline Fixed Effects & Year & Year & Year \\
R2 & 0.893 & 0.895 & 0.877 \\
Number of & 47,034 & 47,026 & 47,423 \\
Observations & & & \\
Number of Clusters & 687 & 687 & 696 \\
\hline
\end{tabular}

Notes: The dependent variable of column (1) and (2) is the natural logarithm of monthly CO2 production computed as $\mathrm{Y}=\log ((\mathrm{kwh} / 1000) * \mathrm{co} 2$ factor $+11.7 *$ therms $)$. The dependent variable of column (3) is Daily Energy (log), which is the natural logarithm of the daily total energy usage in the current month, computed as $\log$ ((curr_electricity_usage+curr_gas_usage*100000/3413)/curr_days). Refer to the Appendix for variable definitions. Standard errors in brackets are clustered by hotel. ${ }^{* * *} \mathrm{p}<0.01,{ }^{* *} \mathrm{p}<0.05,{ }^{*} \mathrm{p}<0.1$ 


\section{Table 4}

\section{Regression Results}

\section{Hotel Electricity Efficiency Trends}

\begin{tabular}{|c|c|c|c|c|c|c|}
\hline & $(1)$ & $(2)$ & (3) & (4) & (5) & (6) \\
\hline HDD_K & $\begin{array}{c}0.445^{* * *} \\
{[0.029]}\end{array}$ & $\begin{array}{c}0.535^{* * *} \\
{[0.031]}\end{array}$ & $\begin{array}{c}0.431^{* * *} \\
{[0.029]}\end{array}$ & $\begin{array}{c}0.472^{* * *} \\
{[0.031]}\end{array}$ & $\begin{array}{c}0.750^{* * *} \\
{[0,09]}\end{array}$ & $\begin{array}{c}0.311^{* * *} \\
{[0.169]}\end{array}$ \\
\hline CDD_K & $\begin{array}{l}1.280^{* * *} \\
{[0.047]}\end{array}$ & $\begin{array}{c}1.407^{* * *} \\
{[0.05]}\end{array}$ & $\begin{array}{l}1.260 * * * \\
{[0.047]}\end{array}$ & $\begin{array}{l}1.321^{* * *} \\
{[0.050]}\end{array}$ & $\begin{array}{c}0.652 * * * \\
{[0.170]}\end{array}$ & $\begin{array}{c}1.462 * * * \\
{[0.341]}\end{array}$ \\
\hline HDD_K ${ }^{2}$ & $\begin{array}{c}0.191 * * * \\
{[0.022]}\end{array}$ & $\begin{array}{c}0.132 * * * \\
{[0.023]}\end{array}$ & $\begin{array}{l}0.19 * * * \\
{[0.022]}\end{array}$ & $\begin{array}{c}0.158^{* * *} \\
{[0.023]}\end{array}$ & $\begin{array}{c}0.103 \\
{[0.070]}\end{array}$ & $\begin{array}{c}0.115 \\
{[0.125]}\end{array}$ \\
\hline CDD_K ${ }^{2}$ & $\begin{array}{c}-0.370 * * * \\
{[0.059]}\end{array}$ & $\begin{array}{c}-0.454 * * * \\
{[0.061]}\end{array}$ & $\begin{array}{c}-0.343^{* * *} \\
{[0.059]}\end{array}$ & $\begin{array}{c}-0.365^{* * *} \\
{[0.061]}\end{array}$ & $\begin{array}{l}-0.039 \\
{[0.220]}\end{array}$ & $\begin{array}{c}-1.214 * * * \\
{[0.469]}\end{array}$ \\
\hline Trend & $\begin{array}{c}0.000 \\
{[0.000]}\end{array}$ & $\begin{array}{c}-0.003 * * * \\
{[0.000]}\end{array}$ & $\begin{array}{l}0.000 * * \\
{[0.000]}\end{array}$ & $\begin{array}{c}-0.004^{* * * *} \\
{[0.000]}\end{array}$ & $\begin{array}{r}0.000 \\
{[0.000]}\end{array}$ & $\begin{array}{c}-0.003^{* * *} \\
{[0.001]}\end{array}$ \\
\hline Trend *CA & $\begin{array}{c}-0.004^{* * *} \\
{[0.000]}\end{array}$ & $\begin{array}{c}-0.004^{* * *} \\
{[0.000]}\end{array}$ & $\begin{array}{c}-0.003^{* * *} \\
{[0.000]}\end{array}$ & $\begin{array}{c}-0.003^{* * *} \\
{[0.000]}\end{array}$ & $\begin{array}{l}-0.001 \\
{[0.000]}\end{array}$ & $\begin{array}{c}-0.004 * * * \\
{[0.002]}\end{array}$ \\
\hline Trend *International & $\begin{array}{l}0.008^{* * *} \\
{[0.000]}\end{array}$ & & $\begin{array}{c}0.008 * * * \\
{[0.000]}\end{array}$ & & & \\
\hline Trend *Vote_Dem & & $\begin{array}{c}0.006^{* * *} \\
{[0.000]}\end{array}$ & & $\begin{array}{c}0.008^{* * *} \\
{[0.000]}\end{array}$ & & \\
\hline $\begin{array}{l}\text { Energy Cost } \\
\text { (in logs) }\end{array}$ & & & $\begin{array}{c}-0.171^{* * *} \\
{[0.013]}\end{array}$ & $\begin{array}{c}-0.259 * * * \\
{[0.014]}\end{array}$ & & \\
\hline Intercept & $\begin{array}{c}3.381^{* * *} \\
{[0.009]}\end{array}$ & $\begin{array}{c}3.342 * * * \\
{[0.010]}\end{array}$ & $\begin{array}{c}2.866^{* * *} \\
{[0.041]}\end{array}$ & $\begin{array}{c}2.762 * * * \\
{[0.032]}\end{array}$ & $\begin{array}{c}3.893 * * * \\
{[0.030]}\end{array}$ & $\begin{array}{c}12.115^{* * *} \\
{[0.065]}\end{array}$ \\
\hline Fixed Effects & Hotel & Hotel & Hotel & Hotel & Hotel & Hotel \\
\hline $\mathrm{R}^{2}$ & 0.207 & 0.200 & 0.216 & 0.220 & 0.207 & 0.03 \\
\hline Observations & 51,306 & 48,690 & 51,210 & 48,667 & 47,034 & 47,034 \\
\hline
\end{tabular}

Notes: The dependent variables of columns (1) - (4) are the natural logarithm of hotel's electricity usage per occupied room in the current month. The dependent variable of column (5) is the natural logarithm of a hotel's total energy usage (electricity and natural gas) per occupied room in the current month. The dependent variable of column (6) is the natural logarithm of a hotel's total CO2 production per occupied room in the current month. This table presents five estimates of equation (2). Refer to the Appendix for variable definitions. Standard errors in brackets are clustered by hotel. ${ }^{* * *} \mathrm{p}<0.01,{ }^{* *} \mathrm{p}<0.05,{ }^{*} \mathrm{p}<0.1$ 